\title{
Characterization of biosurfactant produced by Bacillus Sp. isolated from oil spilled water samples of arabian sea
}

\begin{abstract}
Pollution of Sea by various harmful hydrocarbons due to accidental leakages of oils during ship operations making it one of serious environmental issues all over the world. Biosurfactants act as one of the promising candidates for overcoming such pollutions. They are surface active molecules synthesized by microorganisms. They replace their chemically synthesized counterparts due to their eco-friendly nature on environment. In present study, we isolated some of the bacterial strains showing biosurfactant activity and further we characterized particular bacterial strain showing highest activity isolated from oil-spilled area of Arabian Sea. Various biosurfactant activity assay tests were performed for isolating the potent bacterial strain. Marine biosurfactants produced by some marine microorganisms have been paid more attention, particularly for the bioremediation of the sea polluted by crude oil. Among all of the isolated strains, strain 2 identified as Bacillus sp. showed the highest biosurfactant activity. The isolated culture filtrate was found to be highly effective in microbial enhanced oil recovery (MEOR).
\end{abstract}

Keywords: biosurfactant, Bacillus sp., microbial enhanced oil recovery, oil spilled area
Volume 2 Issue 3 - 2017

\section{Seema Dhail}

Department of Basic Sciences, Manipal University, India

Correspondence: Seema Dhail, Department of Basic Sciences, Manipal University, India, Tel +9I-952I465279,

Email seemaresearch21@gmail.com

Received: March 13, 2017 | Published: April 13, 2017

\section{Introduction}

Accidental leakages and stranding of tankers are some of the major reasons to cause sea pollution. According to the New Zealand government an oil spill from a grounded container ship in the Bay of Plenty has killed 1,250 seabirds on $10^{\text {th }}$ October, 2011 with hundreds of others in rescue centers. ${ }^{1}$ Microbial compounds, which exhibit pronounced surface activity, are classified as biosurfactants. The oil spills from marine water are treated using bioremediation methods using biosurfactant as it is one of the promising technologies in future. Biosurfactants are considered as heterogenous group of surface active molecules produced by microorganisms, which either adhere to cell surface or are excreted extracellularly in the growth medium. ${ }^{2-4}$ They have both hydrophilic and hydrophobic portion showing unique amphiphatic properties. As a result, they can partition preferentially at the interfaces ${ }^{5}$ and environmentally compatibility. ${ }^{6}$ A number of marine bacterial strains can produce biosurfactants during growth on hydrocarbons and also they show eco-friendly nature towards environment while comparing with the synthetically synthesized surfactants. $^{7}$ Such reasons made biosurfactants preferable to those of synthetic surfactants. For improving the recovery of crude oil from reservoir rocks by using microorganisms and their metabolic by products microbial enhanced oil recovery (MEOR) is a good alternative. Recently whole cells and their biosurfactants are used to improve the efficiency of oil recovery by many investigations on MEOR.$^{8-12}$ Microorganisms can contribute to increased oil production by producing biosurfactants and biopolymers on the cell surface, by producing gases and acids to recover trapped oil and microorganisms can selectively plug high permeability channels into the reservoir. ${ }^{13}$ The main objective of this paper is to isolate and characterize most potent biosurfactant producing bacteria from oil spilled areas of Arabian Sea.

\section{Materials and methods}

\section{Isolation and enrichment of biosurfactant producing microorganisms}

Marine samples were collected from different oil spilled areas i.e., oil polluted sea water of Arabian Sea. Geographical description of sample site was latitude 18.94 \& longitude is 72.9. Each sample was loaded into sterile $250 \mathrm{ml}$ flasks. The samples were collected in plastic bags and in sterilized bottles and immediately transported to the Microbiology lab, IIS University, Jaipur, India, and stored in a refrigerator at $4^{\circ} \mathrm{C}$ up to further processing. The samples were spread on a nutrient agar (Difco, USA), dissolved in distilled water and incubated at room temperature for 1 to 2 days. After incubation, plates were enumerated and morphologically different bacteria were selected for biosurfactant screening (approximately 5 to 6 isolates per plate) and purified by re-streaking twice. Isolated colonies were inoculated into $100 \mathrm{ml}$ of Marine Broth 2216 (Difco) containing 2 to 3 drops of petrol+kerosene + diesel $(\mathrm{P}+\mathrm{K}+\mathrm{D})$ in 1:1:1 ratio, and incubated with continuous shaking (200 rpm) for 24 to $48 \mathrm{~h}$ at room temperature using a shaker. Colonies possessing biosurfactant-producing activity, as evidenced by emulsification of oil, were chosen for further experimentation. In addition, the cell suspensions of isolated strains were tested for presence of surfactant by using haemolytic activity, the qualitative drop collapsing test, quantitative oil displacement test and emulsification activity.

\section{Screening for biosurfactant producers}

Haemolytic activity: Biosurfactant producing capacity was found to be associated with haemolytic activity. Haemolytic activity therefore appears to be a good screening criterion for surfactant-producing strains. Isolated strains were screened on blood agar plates containing 
$5 \%(\mathrm{v} / \mathrm{v})$ goat blood and incubated at room temperature for $24 \mathrm{~h}$. Haemolytic activity was detected as the occurrence of a define clear zone around a colony. ${ }^{14}$

Drop collapsing test: Two micro-liter of mineral oil was added to each well of a 96-well micro-liter plate lid. The lid was equilibrated for $1 \mathrm{~h}$ at room temperature, and then $5 \mu \mathrm{l}$ of the cultural supernatant was added to the surface of oil. The shape of the drop on the oil surface was inspected after $1 \mathrm{~min}$. Biosurfactant-producing cultures giving flat drops were scored as positive ' + '. Those cultures that gave rounded drops were scored as negative '-', indicative of the lack of biosurfactant production. ${ }^{15}$

Oil activity assay test: The isolates present in the clearing zone on Haemolytic activity test were re-screened by hydrolyzing oil activity assay on oil agar plates. ${ }^{16}$ Potential biosurfactant-producing strains were inoculated into the MSM (Himedia), and the cultured filter was further analyzed by improved degreasing effect assay test and emulsification activity measurement. Improved degreasing effect assay was carried out following $\mathrm{Bi}$ et al. ${ }^{17}$ The emulsification activity was determined by adding $5 \mathrm{ml}$ of kerosene and an equal volume of cell-free supernatant to a $20 \mathrm{ml}$ tube. The sample was homogenized in a vortex at high speed for $2 \mathrm{~min}$ and allowed to settle for $24 \mathrm{~h}$. The emulsification index was then calculated by given formula.

$$
\text { Emulsification Activity }=\frac{\text { Height of emulsion layer }}{\text { Total height }}
$$

\section{Identification of potential strain}

The potential strain that was showing good biosurfactant activity was identified using Bergey's manual of determinative bacteriology. ${ }^{18}$

\section{Microbial enhanced oil recovery (MEOR)}

The MEOR process was carried out by the sand pack method described by Abu-Ruwaida et al. ${ }^{19}$ Hydrocarbon saturated sand pack column was treated with the culture filtrate and cell-free supernatant at $30^{\circ} \mathrm{C}$. Distilled water served as the control. The oil displacement rate $(\%)=(\mathrm{M} 2 / \mathrm{M} 1) \times 100(\mathrm{M} 1$ : oil content in the sand $(\mathrm{g})$; M2: wash out oil content $(\mathrm{g})$. The assay was repeated three times with three replications for each treatment.

\section{Results and discussion}

Present study revealed that biosurfactant produced by various microbes can reduce pollution of Sea that occurred due to various human activities. Chemical treatment has several disadvantages. Thus biological treatment may be preferred due to their eco-friendly nature, low toxicity, biodegradable and biocompatible and selective. ${ }^{5}$ The primary screening of biosurfactant producing bacteria was carried out using hemolytic activity. Selection of these methods was due to their strong advantages including simplicity, low cost, quick implementation and use of relatively common equipment that is accessible in almost every microbiological laboratory; however, as expected, these methods are not perfect. In the hemolytic method, there are many bio-products that can cause red blood cell lysis which do not necessarily have to be surface actives molecules as mentioned by Youssef et al. ${ }^{20}$ Therefore, drop collapsing test, Oil activity assay test and emulsification activity measurement were used to screen the biosurfactant producer. ${ }^{21-23}$ The drop collapse method depends on the principle that a drop of liquid containing a biosurfactant collapses and spreads over the oily surface. There is a direct relationship between the diameter of the sample and concentration of the biosurfactant and in contrast, the drop lacking biosurfactant remains beaded due to the hydrophobicity of the oil surface that cause aggregation of droplets, but this method is not sensitive in detecting low levels of biosurfactant production. Emulsion activity using different hydrocarbons including $(\mathrm{P}+\mathrm{K}+\mathrm{D})$ and $\mathrm{n}$-hexadecane. Amiriyan et al. ${ }^{23}$ suggested that emulsifier activity depends on the affinity of bioemulsifier for hydrocarbon substrates which involves a direct interaction with hydrocarbon itself rather than an effect on surface tension of the medium. This study revealed that strain 2 detected as Bacillus sp. out of 15 isolated strains had shown the higher biosurfactant activity. Among the 15 isolates, 5 formed a hydrolyzing oil spot on the oil agar plate, and were considered potential biosurfactant-producing isolates. Moreover, as determined by improved degreasing effect assay, strain 2 showed the highest emulsification activity $(60.2 \pm 0.10)$ and oil displacement test $(2.15 \pm 0.03)$ as shown in Table 1. This isolate was characterized as Gram positive. The morphology of the colonies, as well as the physiological and biochemical characteristics of the strain, is shown in Table 2. It was therefore found as Bacillus sp. The oil displacement rates caused by the fermentation broth and culture filtrate (except for the cell) at $30^{\circ} \mathrm{C}$ were $65 \%$ and $62.5 \%$ respectively, whereas those caused by bacterial cell suspensions and distilled water were $10.8 \%$ and $9.2 \%$, respectively. The results showed that both the fermentation broth and culture filtrate (except for the cell) produced by Bacillus sp. was highly effective in recovering crude oil from the sand pack column. The main advantages of microbiological method of bioremediation of hydrocarbon polluted sites are use of biosurfactant producing bacteria without necessarily characterization of the chemical structure of the surface active compounds. The cell free culture broth containing the biosurfactants can be applied directly or by diluting it appropriately to the contaminated site. The other benefit of this approach is that the biosurfactants are very stable and effective in the culture medium that was used for their synthesis. ${ }^{24}$ Their ability for emulsification activity makes them new potential candidates for biosurfactant and bioemulsion production.

Table I Oil displacement activity, emulsification activity and drop collapsing test of cultural supernatant from different-different strains

\begin{tabular}{lllll}
\hline Bacterial strain & Emulsification activity $(\%)$ & Oil displacement test $\left.\mathbf{( c m}^{2}\right)$ & Drop collapsing test & Haemolytic activity \\
\hline Control & $0 \pm 0$ & $0+0$ & - & - \\
Strain I & $39.0 \pm 0.18$ & $1.01 \pm 0.03$ & + & + \\
Strain 2 & $60.0 \pm 0.10$ & $2.15 \pm 0.03$ & + & + \\
Strain 3 & $45.0 \pm 0.20$ & $1.03 \pm 0.01$ & + & + \\
Strain 4 & $35.0 \pm 0.12$ & $1.05 \pm 0.01$ & + & + \\
Strain 5 & $20.0 \pm 0.17$ & $1.03 \pm 0.03$ & + & + \\
\hline
\end{tabular}

*Control is having sterilized sea water having $\mathrm{P}+\mathrm{K}+\mathrm{D}$ 
Table 2 Characterization of bacterial strain 2 showing highest Biosurfactant activity

\begin{tabular}{ll}
\hline Characteristics & Strain 2 (Bacillus sp.) \\
\hline Gram's stain & + \\
Cell shape & Rods \\
Spore & + \\
Motility & + \\
Penicillin sensitivity & + \\
Oxidase & + \\
Urease & - \\
Gelatinase & + \\
Flourescent pigment & + \\
Voges-proskaur test & + \\
Acid from & + \\
D-Glucose & + \\
L-Arabinose & + \\
D-Xylose & + \\
D-Manitol & + \\
Gas from glucose & + \\
Casein & + \\
Gelatin & + \\
\hline
\end{tabular}

\section{Acknowledgements}

None.

\section{Conflict of interest}

The author declares no conflict of interest.

\section{References}

1. Sukhada T. Oil spill damage to soil irreversible:Report. The Times of India. Bennett, Coleman \& Co. Ltd. India, 2011.

2. Fietcher A. Biosurfactant moving toward industrial application. Trends Biotechnol. 1992;10(6):208-217.

3. Zajic JE, Stiffens W. Biosurfactants. CRC Rev, Biotechnol. 1994;1:87106.

4. SS Cameotra, RS Makkar. Synthesis of biosurfactants in extreme conditions. Appl Microbiol Biotechnol. 1998;50(5):520-529.

5. Desai JD, Banat IM. Microbial production of surfactants and their commercial potential. Microbiol Mol Biol Rev. 1997;61(1):47-64.
6. Georgiou G, Lin SC, Sharma MM. Surface active compounds from microorganisms. Biotechnology (N Y). 1990;10(1):60-65.

7. Bertrand JC, Bonin P, Goutx M, et al. Biosurfactant production by marine microorganisms:potential application to fighting hydrocarbon marine pollution. J Mar Biotechnol. 1993;1:125-129.

8. Joshi S, Bharucha $\mathrm{C}$, Jha $\mathrm{S}$, et al. Biosurfactant production using molasses and whey under thermophilic conditions. Biores Technol. 2008;99:195-199.

9. Toledo FL, Gonzalez J, Calvo C. Production of bioemulsifier by Bacillus subtilis, Alcaligenes faecalis and Enterobacter species in liquid culture. Bioresour Technol. 2008;99(17):8470-8475.

10. Jinfeng L, Lijun M, Bozhong M, et al. The field pilot of microbial enhanced oil recovery in a high temperature petroleum reservoir. $J$ Pet Sci Eng. 2005;48:265-271.

11. Rashedi H, Jamshidi E, Mazaheri Assadi M, et al. Isolation and production of biosurfactant from Pseudomonas aeruginosa isolated from Iranian southern wells oil. Environ Sci Technol. 2005;2(2):121-127.

12. Mei S, Wei L, Guangzhi L, et al. Laboratory study on MEOR after polymer flooding. Proceedings of the SPE International Improved Oil Recovery Conference in Asia Pacific. Kuala Lumpur, Malaysia, 2003.

13. Bryant RS. Potential uses of microorganisms in petroleum recovery technology. Proc Okla Acad Sci. 1987;67:97-104.

14. PG Carrilo, C Mardaraz, SI Pitta Alvarez, et al. Isolation and selection biosurfactant-producing bacteria. World J Microbiol Biotechnol. 1996;12(1):82-84.

15. Youssef NH, Dunacn KE, Nagle DP, et al. Comparison of methods to detect biosurfactant production by diverse microorganism. J Microbiol Methods. 2004;56(3):339-347.

16. Morikawa $\mathrm{M}$, Daido $\mathrm{H}$, Takao $\mathrm{T}$, et al. A new lipopeptide biosurfactant produced by Arthrobacter sp. strain MIS 38. J Bacteriol. 1993;175(20):6459-6466.

17. Bi SN, Wang YJ, Zuo YH. Improvement and application of oil spreading to detect biosurfactant. J Heilongjiang Bayi Agric Univ. 2009;6:58-60.

18. Buchanan RE, Gibbons NE. Bergey Manual of Determinative Baeteriology. 8th ed. USA: The WoIliams \& Wilkins company; 1974. p. 529-545.

19. Abu Ruwaida AS, Banat IM, Hadirto S, et al. Isolation of biosurfactant producing bacteria-product characterization and evalution. Acta Biotechnol. 1991;11(4):315-324.

20. Dhail S, Jasuja ND. Isolation of biosurfactant producing marine water Afr J Environ Sci Technol. 2012;6(6):263-266.

21. Dhail S. Isolation of potent Biosurfactant producing bacteria from oil spilled marine water and marine sediments. Afr J Biotechnol. 2012;11(103):16751-16757.

22. Dhail S. Microbial enhanced oil recovery using potent Biosurfactant produced by Pseudomonas sp. from Arabian Sea, Mumbai. J Petroleum Gas Eng. 2013;4(3):57-60.

23. Amiriyan A, Mazaheri Assadi M, Sajadian VA, et al. Bioemulsan production by Iranian oil reservoirs microorganism. Iranian $J$ Env Health Sci Eng. 2004;1(2):28-35.

24. MP Płociniczak, GA Płaza, ZP Seget, et al. Environmental Applications of Biosurfactants:Recent Advances. Int J Mol Sci. 2011;12(1):633-654. 